\title{
La prosperidad y la codicia: transformaciones en los repertorios morales y políticos en una ciudad intermedia de la Costa Atlántica bonaerense
}

Prosperity and Greed: Transformations in Moral and Political Repertoires in a Middle-Sized City on the Atlantic Coast of the Buenos Aires Province (Argentina)

A prosperidade e a cobiça: transformações nos repertórios morais e politicos em uma cidade intermédia da Costa Atlântica bonaerense

Gabriel David Noel ${ }^{*}$

Recibido: 1 de agosto de 2015

Aprobado: 29 de septiembre de 2015

Doi: dx.doi.org/10.12804/territ35.2016.05

\section{Para citar este artículo:}

Noel, G. (2016). La prosperidad y la codicia: transformaciones en los repertorios morales y políticos en una ciudad intermedia de la Costa Atlántica bonaerense. Territorios, 35, 101-125. Doi: dx.doi.org/10.12804/ territ35.2016.05

\begin{abstract}
* Doctor en Ciencias Sociales Universidad Nacional General de Sarmiento (UNGS). Lic. en Antropologia (UNLP) IDAESUNSAM/CONICET. Secretario de Investigación (IDAES-UNSAM), Investigador Adjunto (UNSAM, CONICET, IDAES) Núcleo de Estudios Sociales Urbanos (IDAES/ UNSAM). Correo electrónico:gdnoel@gmail.com
\end{abstract}


Palabras clave

ciudades intermedias, procesos de valorización,

lucro, moralidades, capital político, desarrollo territorial, ciudades balnearias.

Keywords

Middle-sized Cities, Valuation Processes, Wealth, Moralities, Political Capital, Territorial Development, Seaside Resorts.

Palavras-chave cidades intermédias, processos de valorização,

lucro, moralidades, capital politico, desenvolvimento territorial, cidades balneárias.

territarias 35

\section{RESUMEN}

A mediados del siglo XX, Villa Gesell (a unos $350 \mathrm{~km}$ de Buenos Aires, en la costa atlántica bonaerense) surge como una de las localidades de mayor crecimiento urbano en Argentina. A partir de un proceso de desarrollo impulsado por la valorización de la tierra, la especulación inmobiliaria y el desarrollo de actividades comerciales vinculadas con el turismo, una serie de emprendedores locales conseguirá asegurarse una posición económica preeminente que, consagrada en una serie de repertorios morales canónicos, será convertida en una legitimidad política que les permitirá mantener su preeminencia durante casi tres décadas. Sin embargo, sobre el final del siglo, los recursos morales que volvieran posible esta conversión comenzarán a ser impugnados y disputados. A su debido tiempo, recursos alternativos serán articulados en una nueva narrativa histórica, que habilitará también un proceso de conversión mediante el cual nuevos actores buscarán construir su propia legitimidad política en disputa con sus predecesores. Sobre esa base, el presente texto busca reconstruir el proceso de surgimiento de este nuevo repertorio de impugnación, sus principales contenidos y la manera en que estos serán movilizados en los inicios de un proceso de disputa moral y política entre actores de viejo y nuevo cuño.

\section{ABSTRACT}

By the middle of the twentieth century, Villa Gesell (located on the Atlantic coast about $350 \mathrm{~km}$ from Buenos Aires) became one of the fastest growing cities in Argentina. Through a rapid process of development fueled by land valuation, real estate speculation and commercial activities related to tourism, a small group of local entrepreneurs was able to secure a preeminent economic position, which in time, and sanctioned by a series of canonic moral repertoires, would convert into a political legitimacy which would allow the group to hold the reins of the city for more than three decades. By the end of the century, however, the moral resources that made this conversion possible would become disputed and challenged. In due time, alternative resources would be assembled within the frame of a new historical narrative, which would enable another process of conversion through which novel actors would seek to build their own legitimacy, disputing their predecessors'. On that basis, the following paper seeks to retrace the origins of this new repertoire, its main contents, and outline some of the ways in which they would be mobilized on the verge of a recent process of moral and political dispute between old and new political actors.

\section{RESUMO}

A mediados do século XX, Villa Gesell (a uns $350 \mathrm{~km}$ de Buenos Aires, na costa atlântica bonaerense) surge como uma das localidades de maior crescimento urbano na Argentina. A partir de um processo de desenvolvimento impulsado pela valorização da terra, a especulação imobiliária e o desenvolvimento de atividades comerciais vinculadas com o turismo, uma série de empreendedores locais conseguirá assegurar-se uma posição económica preeminente que, consagrada em uma série de repertórios morais canónicos, será convertida em uma legitimidade política que lhes permitirá manter a sua preeminência durante quase três décadas. No entanto, no fim do século, os recursos morais que fizeram possível esta conversão, começarão a ser impugnados e disputados. Ao seu devido tempo, recursos alternativos serão articulados em uma nova narrativa histórica, que habilitará 
também um processo de conversão mediante o qual novos atores buscarão construir a sua própria legitimidade política em disputa com os seus predecessores. Sobre essa base, o presente texto busca reconstruir o processo de surgimento deste novo repertório de impugnação, os seus principais conteúdos e a maneira em que estes serão mobilizados nos inícios de um processo de disputa moral e política entre atores de velha e nova geração.

\section{Introducción}

Como parte de una serie de medidas destinadas al saneamiento fiscal y el ordenamiento administrativo (Regalsky \& Da Orden, 2013), el gobierno de la provincia de Buenos Aires emprendió sobre finales del primer decenio del siglo XX un procedimiento de actualización catastral de los predios rurales del interior provincial. El resultado del mismo reveló que muchos de sus propietarios ocupaban una superficie mayor a la que les correspondía por derecho. Así las cosas, la administración ofreció a estos ocupantes irregulares dos opciones: o bien la compra de ese excedente a un precio preferencial y la correspondiente revaluación de los lotes, o bien la cesión de una cantidad de hectáreas equivalentes a la diferencia, que pasarían entonces a manos del estado provincial en calidad de sobrante fiscal.

Las elecciones se dividieron. Algunos de los propietarios - es el caso de la familia Guerrero, cuyas propiedades se extendían al sur de la Bahía de Samborombón, en el partido de General Madariaga - optan por la compra. Otros - como sucede con los Leloir, sus vecinos inmediatos hacia el surdecidieron deshacerse del sobrante (Benseny, 201l; García \& Palavecino, 2006).
Huelga decir que a la hora de demarcar las hectáreas supernumerarias que habrían de pasar a manos del erario público, los ocupantes ceden las que se encuentran en los cordones arenosos y áridos lindantes con el litoral costero, improductivos y estériles, a espaldas de las fértiles tierras ganaderas de la pampa húmeda que les habían permitido hacer fortuna ${ }^{1}$.

Una vez puestos a la venta, los lotes en cuestión conocerán una sucesión de emprendimientos fallidos o truncos. Un residente de la cabecera del partido, alentado por la presencia de cerdos salvajes en los montes cercanos a los cordones dunícolas, adquiere los predios con el fin de instalar corrales para la crianza de porcinos. Como descubrirá muy pronto, la aridez del terreno no resulta demasiado propicia para esta actividad, razón por la cual cede nuevamente las tierras a la provincia. Lo sucede Emilio Credaro, que ante las dificultades experimentadas por su predecesor decide hacer de la necesidad virtud y comercializar el recurso más abundante de la zona: la arena, materia prima muy solicitada en una Buenos Aires en rápida expansión. Pero los costos de transporte suponen una desventaja insuperable frente a la abundancia del recurso provisto por el continuo dragado del Río de la Plata, en las adyacencias de
${ }^{1}$ Una caracterización sumamente gráfica de la oposición entre la fertilidad de la pampa ganadera, y la esterilidad de la costa maritima puede encontrarse en la célebre obra gauchesca de Ricardo Güiraldes, Don Segundo Sombra (Güiraldes, 1955, qqv. Pastormerlo, 1996). 
${ }^{2}$ La plantación de pinos de Guerrero, comenzada en 1920, habría de dar origen con el tiempo a la localidad balnearia de Cariló.

${ }^{3}$ Carlos Idabo Gesell era bijo de Silvio Gesell (18621930), un notorio emprendedor y autodidacta preocupado por problemas de teoría económica, y que habría de adquirir una fugaz notoriedad a fines del siglo $X I X$ y principios del $X X$, en particular a partir de los elogios que le prodigara Milton Keynes (Keynes, 1997, p. 312ss). El nombre de la ciudad en cuestión será explicitamente presentada por Carlos Gesell como un homenaje a la obra y el genio de su padre.

\section{territarias 35}

la metrópoli, y una vez más el optimismo inicial de este nuevo entrepeneur habrá de revelarse prematuro (Ortiz, 2010).

Haciendo honor el célebre adagio acerca de las terceras oportunidades, el propietario siguiente habrá de conocer, a fuerza de obstinación, un éxito tan resonante como imprevisto. Carlos Idaho Gesell, un inventor y emprendedor autodidacta - propietario junto con su hermano de una fábrica de muebles para niños moderadamente próspera en la ciudad de Buenos Aires - decide adquirir las tierras puestas a la venta por Credaro. Algunas fuentes indican que la decisión de compra habría sido suscitada por una conversación que Gesell habría mantenido con Héctor Guerrero (Saccomanno, 1994, p. 21) - propietario, como ya hemos mencionado, de las tierras al norte de las de Credaro- quien se encontraba llevando adelante desde hacía una década y con un éxito considerable una plantación de pinos en la porción de su heredad adyacente a la costa (Sierra, 1969; Gesell, 1983) ${ }^{2}$. Carlos Gesell habría concebido así la posibilidad de emprender una plantación similar, la cual combinada con la instalación de un aserradero le permitiría hacerse con madera para su fábrica de muebles a un costo inferior al supuesto por el recurso a sus proveedores habituales en la lejana provincia de Misiones (Ortiz, 2010; Saccomanno, 1994). Así es que adquiere de Credaro 1.648 hectáreas, en junio de 1931.

Como sucediera con sus predecesores, sin embargo, el doble proyecto de plantación y aserradero se revelará mucho más elusivo de lo previsto, y su artífice habrá de acumular una serie de fracasos que muy probablemente hubieran desanimado a un personaje menos obstinado (Noel, 2012). Los proyectos se suceden de manera tan prolífica como indisciplinada: un criadero de aves, un nuevo intento de criar porcinos, cabras, colmenas. Todos ellos, más temprano que tarde, se revelan inviables. Finalmente, Carlos Gesell encontrará la forma de alcanzar la sustentabilidad económica de su inversión a través de una actividad notoriamente lejana de la pecuaria o de la silvicultura y por entonces incipiente: el turismo. En efecto, a partir de la construcción inicial de una pequeña vivienda destinada al alquiler estival y una enérgica campaña de boca en boca, la plantación de pinos prevista en el plan original habrá de materializarse, aunque ya no como proveedora de materia prima para una lejana manufactura porteña, sino como el entorno bucólico de una naciente villa turística, que su impensado fundador habrá de bautizar en homenaje a su padre con el nombre de Villa Gesell ${ }^{3}$.

Como ya hemos tenido ocasión de debatir (Noel, 2012), la narración de este sinuoso proceso de creación de valor ha sido inscripta —en el marco de una épica distribuida en una serie de textos de naturaleza histórico-hagiográfica- como el triunfo de la voluntad sobre una naturaleza hostil. "Don Carlos" deviene en estos textos un héroe fáustico, la encarnación del progreso (Berman, 1988), un campeón de la voluntad cuyo eventual triunfo y prosperidad económica - en una clave que hubiese agradado a Weber (1993) — dan 
testimonio de la grandeza de su genio visionario y de su gigantesca estatura moral. El hecho de haber erigido una ciudad pujante en medio de un arenal estéril, y haberla transformado en las décadas subsiguientes en uno de los más prometedores emprendimientos turísticos de la Argentina (Pastoriza, 2011), será presentado y leído en lo sucesivo entre los habitantes de esa misma ciudad como testimonio de la singularidad de su fundador y de la excepcionalidad de su visión. Como lo consignara uno de los hagiógrafos que consagraran esa lectura en el párrafo final de su obra:

La curva de evolución ascendente muestra guarismos que permiten a la Villa ostentar el título de la localidad de más rápido desarrollo en el país. Su asombroso crecimiento geométrico se presenta como un tributo con que la historia retribuyó el esfuerzo de los que empeñaron sus vidas en la legendaria transformación del desierto (Masor, 1995, p. 151, subrayado nuestro).

En esa clave, la consolidación y prosperidad sucesiva de la ciudad, su visibilización como centro de veraneo en la prensa metropolitana, su explosivo crecimiento edilicio y la concomitante expansión de servicios relacionados con la oferta turística (Noel \& de Abrantes, 2014) serán presentados con frecuencia como evidencia apodíctica de un triunfo siempre renovado, que aunque se narra en el lenguaje de la prosperidad y el éxito económico, se transcribe ante todo como una gesta de naturaleza moral (Noel, 2012):
Cuando llegó acá [Don Carlos] no había más que arena... nadie veía más que arena, los tipos que le vendieron esto se deben haber cagado de risa. Pero él la vio, la vio más clara que nadie... vos viste... el que ríe último [ríe mejor]. Veinte años más tarde, más o menos para cuando llegaron mis viejos, ya tenías todo esto, una ciudad con oportunidades, oportunidades de laburo, de crecer, de progresar... [Don Carlos] era un jodido, pero el tipo creo riqueza de la nada... de la arena... vio la oportunidad donde nadie la había visto... y laburó para hacerla realidad... por eso es un grande, más allá de que sí, era un jodido (Eduardo, 57 años, hijo de "pioneros").

Ahora bien, aun cuando esta lectura de la creciente y sostenida prosperidad económica de la ciudad como evidencia de la excepcionalidad moral de su fundador - y a fortiori de quienes lo secundaron en su empresa desde el principio, los "pioneros"- conocerá una vigencia sumamente prolongada y prácticamente monocorde que habrá de extenderse durante más de cuatro décadas, comenzarán a aparecer sobre finales de siglo una serie de relatos discordantes que con un ímpetu y una radicalidad cada vez mayores propondrán un contrapunto a esta visión de la ciudad y de sus orígenes como gesta virtuosa y como testimonio de la estatura moral de sus artífices. Sustentadas sobre la base de una serie de recursos alternativos de identificación moral que opondrán el 'afán de lucro' a un espíritu libertario y "auténtico" que expresaría "el alma” de la ciudad, estas 
4 "La Villa" es el etnónimo que diversos habitantes y $v i$ sitantes de Villa Gesell -en particular los que migraron alli o la conocieron como turistas antes de los noventautilizan con frecuencia para referirse a la ciudad. Apenas hace falta aclarar que está desprovisto de todas las connotaciones estigmatizantes asociadasal término "villa" en el imaginario de lossectores medios metropolitanos de la Argentina ( $G u$ ber, 2003), en la medida en que su uso original remite a un periodo histórico previo al de la popularización de este último como sinónimo de "villa de emergencia" o "villa miseria" (Ratier, 1973). Los visitantes y residentes más jóvenes de la ciudad rara vez utilizan este término, y suelen referirse a la ciudad con la apócope de "Gesell". Haciéndonos eco de este uso familiar y extendido, utilizaremos el apelativo coloquial de "la Villa" para referirnos a la ciudad a lo largo del texto.

${ }^{5}$ A la luz de este marco más amplio, el presente texto prolonga reconstrucciones previas de los repertorios que denominamos "de los pioneros” (Noel, 2012), "del hippismo/contestatario" (Noel, 2014b) y "de los emprendedores” (Noel, 2011) a los cuales por razones de extensión aludiremos de forma sumaria y sinóptica.

\section{territarias 35}

narrativas propondrán una relectura de la épica fundacional precedente que buscará inscribirla como signo de una injusticia fundacional, de un deterioro creciente y de un estancamiento indefinido promovidos por una casta de "fenicios" que más allá de sus protestas de virtud no serían más que oportunistas de ocasión que jamás consiguieron ni conseguirán ver que allá de sus mezquinas posibilidades individuales de hacer dinero a expensas de la ciudad y del resto de sus habitantes. Como veremos en lo sucesivo, quizás el rasgo más sorprendente de la irrupción de estos nuevos repertorios de interpretación moral de la identidad, la historia y la naturaleza de "la Villa" y sus habitantes es la rapidez con que aparecen y se difunden, allí donde poco tiempo antes las caracterizaciones de la ciudad, la lectura de sus orígenes y de su explosivo crecimiento económico en clave de triunfante epopeya moral aparecían como poco menos que unánimes.

Reponer las condiciones y los contornos de esa irrupción y de esa difusión acelerada será precisamente el objetivo del presente texto, que forma parte de una investigación de larga duración sobre la génesis, la difusión, las transformaciones y la movilización de los principales repertorios y recursos morales (Noel, 2013b) en clave identitaria y política, siguiendo la intuición original de Mary Douglas (1986) de que los actores sociales respaldan sus posiciones mediante una serie de argumentos morales que buscan naturalizarlas ${ }^{5}$. Como habremos de ver a lo largo del texto, esta empresa moviliza un tipo de formación político- identitaria análoga a la que Luis Felipe Miguel (Miguel, 1998) denominara mito político, y que involucra un caso particular y extremo de articulación de repertorios en el cual un conjunto de recursos son objeto de una asociación duradera y fuertemente articulada en virtud de su capacidad de condensar en un dispositivo multidimensional una serie de representaciones taquigráficas de una realidad social compleja, que permiten concebirla en términos de totalidad a la vez que vuelven concebible operar sobre ella en virtud de ese mismo carácter unitario.

Así, a través de una reconstrucción histórica de base etnográfica ${ }^{6}$, mostraremos de qué manera determinadas atribuciones de virtud o malicia son construidas y puestas en circulación por diversos actores sociales en el marco de sus disputas en torno de una serie de posiciones políticas cruciales de la ciudad. A estos efectos, procederemos en primer lugar a presentar de manera sinóptica la circulación inicial de una 'épica de la prosperidad' según la cual, como hemos visto, el crecimiento económico de la ciudad fuera interpretado como síntoma virtuoso de su singularidad moral; para proceder seguidamente a presentar la inflexión que hemos anticipado en los párrafos precedentes y en la cual estos relatos comienzan a coexistir con y a ser interpelados por una serie de censuras que imputan a los héroes de otrora - comenzando por el propio Conditor, Carlos Gesell- un materialismo ramplón, una mezquindad egoísta y una (auto)destructiva cortedad de miras. 
Nuestro objetivo al contraponer estos repertorios contrastantes, será dar cuenta de las modalidades de articulación asumidas por determinados procesos históricos y sociológicos por un lado, y estos nuevos recursos y repertorios de impugnación moral por el otro, así como los modos específicos en que determinados actores sociales de la localidad de Villa Gesell interpelan las narrativas otrora hegemónicas sobre su ciudad en las primeras dos décadas de este nuevo siglo. A fortiori, esta reconstrucción etnográfica encuentra su sentido ulterior en su capacidad de iluminar el papel que formaciones mitopoiéticas y morales de esta clase (Miguel, 1998; Noel, 2013b) pueden - y suelen - asumir en las disputas que actores políticos concretos entablan respecto de la acumulación y movilización de recursos centrales a la hora de obtener y conservar tanto una posición predominante, mediante el recurso de legitimar y naturalizar la potestad de su ejercicio (Douglas, 1986).

\section{La prosperidad como virtud}

\section{El camino hacia la riqueza depende fundamentalmente de dos palabras: trabajo y ahorro Benjamin Franklin}

Como hemos visto, el giro tan tardío como imprevisto de Carlos Gesell hacia la actividad turística habrá de permitirle un despegue económico que hasta entonces le resultara esquivo. Como puede suponerse, este despegue fue posibilitado por un pro- ceso de (re)valorización extraordinaria de una tierra antes improductiva y estéril; y acompañó y empujó a la vez una incipiente trayectoria de urbanización que, aunque tímida en principio, habrá de adquirir velocidad creciente (o incluso extraordinaria) en los años subsiguientes.

Así, a menos de tres décadas de la llegada de nuestro inversor porteño al desierto paraje costero cuyas tierras acabara de adquirir y a dos del advenimiento casual del primer turista, un primer ciclo consolidado de expansión estructural, edilicia y demográfica ha transformado a lo que durante mucho tiempo no fuera más que un puñado de propiedades de veraneo perdidas entre dunas irregularmente forestadas, en una población con más de 1.300 residentes permanentes. La localidad naciente dispone para entonces de una escuela primaria y servicios de atención médica, una cooperativa que provee electricidad, estafeta postal y delegación municipal ${ }^{7}$, un servicio de pasajeros desde Buenos Aires y uno de ómnibus urbano e interurbano a la cabecera del partido, una oferta comercial y de servicios relativamente variada, un cine, y más de 25 hoteles en funcionamiento, capaces de albergar más de 6.000 pasajeros en temporada (Guía Turística y Comercial de Villa Gesell, 1959).

Ahora bien, esta expansión urbana y esta diversificación comercial deben mucho al hecho de que tanto el propio Don Carlos como sus colaboradores más cercanos (Ortiz, 2010; Saccomanno, 1994) han logrado convencer y retener a una serie de pequeños y medianos emprendedores de diversas
${ }^{6}$ Nuestro texto se inscribe en el marco de una investigación de base etnográfica que se extendió entre 2008 y 2014 en el partido de Villa Gesell, y que sobre la base de una estrategia amplia de recolección de datos combinó el uso de fuentes bibliográficas y hemerográficas, la realización de historias de vida y entrevistas en profundidad y la observación etnográfica en diversos ámbitos de sociabilidad de las cuatro localidades del partido, así como en coyunturas especificas de la localidad cabecera. Más especificamente, este trabajo recoge los resultados de la realización de 60 historias de vida y entrevistas en profundidad, más de 530 horas de observación sistemática y el trabajo con más de una veintena de textos de circulación extendida entre los habitantes de la ciudad (qv. Noel, 2012).

7 Tanto Villa Gesell como las localidadesvecinasse encontraban bajo la jurisdicción del Municipio de General Madariaga, situación que habrá de prolongarse hasta la concesión de la autonomía por parte del gobierno de facto de la Provincia de Buenos Aires en 1978 (cf. infra). Los detalles de este proceso pueden consultarse en $A A V V$ (2008).

territarias 35

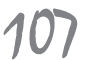


${ }^{8}$ Los de "primera generación" incluyen a quienes secundaron a Don Carlos en su gesta civilizatoria, asi como a una serie de propietarios de origen mitteleuropeo que adquieren residencias de temporada $y$ terminan estableciéndose en ellas en forma permanente a comienzos y mediados de la década del cuarenta'.

${ }^{9}$ Los Inconstantes presenta en sociedad a una localidad hasta entonces desconocida para los sectores medios porteños, y lo hace caracterizándola como un espacio juvenil de libertad y experimentación artistica y sexual, en virtud de lo cual la ciudad comenzará a atraer a amplios sectores de la bohemia y la juventud porteñas, constituyéndose en una suerte de meca de quienes buscaban experimentar con la panoplia de alternativas musicales, teatrales, plásticas, comunitarias, sexuales ofarmacológicas que entraban con tanta rapidez como atractivo en la órbita de los jóvenes de sectores medios urbanos de la década del sesenta (Noel, 2014b).

territarias 35 108 extracciones, provenientes en general de trayectorias sociales no demasiado prósperas que al radicarse como trabajadores y comerciantes hicieron posible sentar las bases para una ciudad que, aunque lejos de la autosuficiencia, permite ya para esa época encontrar algunas de las comodidades mínimas necesarias para establecerse en forma permanente. Son estos migrantes de segunda generación ${ }^{8}$ quienes eventualmente habrán de delimitar - narrativa históricomoral de por medio - ese colectivo (auto) denominado de los “pioneros": los apellidos 'ilustres' de quienes "bicieron la ciudad" (Noel, 2014a).

A su vez, la consolidación de esta primera fase de crecimiento creará las condiciones de posibilidad de una segunda, que habrá de extenderse a lo largo de las dos décadas subsiguientes y que será impulsada ante todo por la especulación inmobiliaria y el mercado de bienes raíces. Este proceso conoce un primer impulso con la promulgación en 1961 de la llamada 'Ordenanza Orgánica del Desarrollo (96/61)’ mediante la cual el ejecutivo municipal prohibía la realización de nuevos loteos allí donde aún se encontraran sin edificar más del 75\% de las parcelas ya aprobadas (AAVV, 2008). Carlos Gesell no tardaría en responder a esta iniciativa, que él consideraba retardataria y arbitraria, con el "Plan Galopante" que concedía un $50 \%$ de descuento sobre el valor final del terreno a quien hubiese terminado de edificar en menos de seis meses contados desde el pago de la primera cuota. En consecuencia las edificaciones comenzarán a proliferar velozmente en las zonas ya adjudicadas, habilitando la expansión a través de nuevos loteos en posición más meridional y atrayendo sucesivos inversores.

Al mismo tiempo la aceleración de este proceso recibe un empuje adicional de la visibilización repentina de la ciudad suscitada por la aparición en 1962 de Los Inconstantes de Rodolfo Kuhn, la primera película ambientada completamente en $\mathrm{Vi}$ lla Gesell que habrá de otorgar a la ciudad que nos ocupa una notoriedad nacional o al menos metropolitana9. Las décadas del sesenta y sobre todo la del setenta abrirán paso en consecuencia a la llegada de un conjunto de pequeños y medianos inversores - y también algunos grandes, aunque no demasiado - atraídos por la perspectiva de invertir en bienes raíces, mediante la compra de terrenos relativamente baratos que permitieran multiplicar la inversión a través del desarrollo inmobiliario y el alquiler o la venta de propiedad inmueble con fines turísticos.

Cabe señalar que incluso antes del Plan Galopante el mismo Carlos Gesell había alentado este proceso especulativo de manera cada vez más enfática y deliberada. El argumento de que comprar lotes en Villa Gesell constituía la mejor inversión a futuro que pudiera concebirse en la Argentina de posguerra había hecho su aparición en el sales pitch de Don Carlos y sus socios desde al menos la década del cincuenta, y en las guías y folletos publicitarios que la Administración Gesell publicaba año tras año se multiplican las declaraciones de esta naturaleza, respaldadas cada vez con mayor fuerza e insistencia por la ya mencionada 
constatación de que "la Villa" era por entonces la ciudad de mayor crecimiento de toda Argentina. En consecuencia, la compra de terrenos en Villa Gesell comenzará a ser considerada por muchos emprendedores metropolitanos una inversión de bajo riesgo y alto rendimiento, más aún en el contexto de una cíclica inestabilidad económica a nivel nacional que da fuerza al sempiterno argumento de que invertir en "tierra y ladrillos" es la mejor idea para protegerse de la inflación, la incertidumbre y la zozobra económica a mediano y largo plazo.

Así es que como resultado de este proceso Villa Gesell terminará de consolidarse, entre comienzos de la década del sesenta y mediados de la década del setenta, como ciudad de veraneo adquiriendo un perfil cada vez más masivo, y en consecuencia procederá a alargarse en paralelo a la costa $\mathrm{y}$ en dirección al sur. Este avance recursivo tendrá como resultado un crecimiento demográfico que prácticamente quintuplicará la población permanente de la Villa entre 1960 y 1970 - año para el cual el Censo Nacional de Población la contabiliza en 6.341 habitantes- y que volverá a duplicarla en la década siguiente, alcanzando para 1980 una población de 11.632 habitantes es decir diez veces más que la contabilizada por el censo de 1960 .

Como hemos ya adelantado, todo este proceso fue glosado - de manera cada vez más articulada y deliberada- mediante el recurso a una serie de tropos que presentaban el carácter explosivo del crecimiento de la ciudad, así como la alta rentabilidad económica que premiaba sus beneficiarios, como una recompensa moral a la fe, al esfuerzo y al trabajo de quienes invertían en ella (Noel, 2012) incluso cuando para entonces esa inversión implicara obtener altos rendimientos con un riesgo que iba de bajo a nulo. La reiteración del tropo de "la ciudad con crecimiento más rápido de la Argentina", la sucesión de epítetos como "pujante" y "prometedora", la invitación a sumarse a un éxito continuo que ya llevaba dos décadas y la autocongratulación de quienes lo habían hecho en épocas pasadas y bajo condiciones más inciertas se acumulaban sin solución de continuidad y con énfasis creciente en las casi tres décadas que median entre la consolidación original de los cincuenta y la obtención de la autonomía municipal en $1978^{10}$. Como nos lo recordara una de nuestros informantes:

[...] en ese entonces veíamos que la ciudad crecía, crecía de un día para otro y era como un milagro... sobre todo para los que recordábamos que hacía poquito, ayer nomás, no había nada. La verdad era que estábamos orgullosos de la ciudad, porque el modo que crecía... era como ver un premio a todo lo que habíamos puesto [en ella]... y cuando salía en los diarios que era la ciudad que más crecía, o que después de Mar del Plata era la que más gente venía [en temporada] todos lo sentíamos como un reconocimiento... como si nos pusieran una medalla (Emilce, 72 años, docente jubilada e hija de “pioneros").
${ }^{10}$ Villa Gesell obtendrá su autonomía municipal el 1 de julio de 1978 de la mano del entoncesgobierno de facto de la Provincia de Buenos Aires, junto con dos jurisdicciones adyacentes y una cuarta localidad balnearia, al sur de la provincia.

territarios 35 109 
${ }^{11}$ La queja permanente expresada por los geselinos a lo largo del proceso que habrá de conducir a la autonomía municipal tenía que ver con el carácter nitidamente rural del municipio de General Madariaga y la visión concomitante de sus autoridades, la cual en palabras de aquéllos se traducía por una torpe miopia respecto del turismo y sus potencialidad económica: "Incluso cuando ya hacia tiempo que [Villa] Gesell levantaba más guita [recaudaba más dinero] que todo el resto del Municipio con sus vacas y sus cosas, los tipos no la veian" (Andrés, 69 años, comerciante jubilado).

12 Informantes y fuentes son unánimes en este sentido: Don Carlos Gesell supeditaba con frecuencia no solo las donaciones, sino asimismo las operaciones estrictamente mercantiles de compra $y$ venta de la tierra a un particular criterio moral. Así, es ubicuamente invocada una anécdota según la cual "el Viejo"-abstemio militante- ofrecía cerrar las operaciones inmobiliarias con un whisky, solo para rehusar firmar el boleto de compraventa cuando el incauto aceptaba de buena fe el ofrecimiento. Otros criterios implicaban cuestiones politicas: así, uno de nuestros informantes nos señaló que "todo el mundo lo sabe,

territarias 35

\section{La Prosperidad como Fundamento y Garantía de Legitimidad Política}

Ahora bien: si durante las primeras tres décadas de su existencia efectiva el carácter periférico de la ciudad y su dependencia política y administrativa de una sede municipal lejana - tanto en el aspecto literalmente geográfico como en el relativo a la visión estratégica del desarrollo (AAVV, 2008 $)^{11}$ así como la presencia autoritaria y paternalista (Sennett, 1982) de Don Carlos - que seguía manteniendo un férreo control sobre su ciudad y la propiedad de buena parte de la tierra, que distribuía discrecional e incluso caprichosamente ya mediante ventas, ya mediante cesiones gratuitas ${ }^{12}$ - planteaban $^{2}$ límites objetivos a quienes aspiraran a participar del control (o más modestamente de la gestión) de la cosa pública de la Villa, la llegada de la autonomía primero y el deceso del Fundador poco tiempo después ${ }^{13}$, habrá de dar vuelo a una serie de actores cuya presencia institucional y cuya fuerza en los asuntos públicos de la ciudad se volvían cada vez más visibles ${ }^{14}$. Se trataba por regla general de medianos empresarios y comerciantes, sobre todo de los sectores hotelero, gastronómico e inmobiliario, a los que se sumaban miembros destacados de profesiones liberales. Aun cuando no constituían una 'clase política' de pleno derecho, lo cierto es que estos actores registraban un peso considerable en la vida económica e institucional de la ciudad, en virtud del cual comenzarán a tener una presencia creciente y una influencia cada vez mayor en el naciente municipio de Villa Gesell, sobre todo durante el proceso de acumulación originaria de capital político en los años inmediatamente posteriores a la restauración democrática ${ }^{15}$. Como no se cansaran de recordarnos nuestros informantes, los candidatos a intendente $-\mathrm{y}$ a fortiori los propios intendentes - ungidos durante los primeros veinte años de vida democrática o bien surgieron directamente de este sector, o bien accedieron al poder con la bendición de sus principales adalides (Noel, 2014a) y, en este sentido, la llegada de la autonomía habría permitido a este grupo consolidar de modo definitivo y conservar en lo sucesivo el control político de la ciudad. Correlativamente, esto implica que los intendentes electos habrían sido capaces de obtener y conservar su legitimidad solo mientras pudieran retener el apoyo de estos sectores económicamente prominentes, lo cual a su vez requería gobernar “para ellos". En palabras de uno de nuestros informantes:

[...] los que ahí ponían y sacaban [Intendentes] eran los tipos que movían la tarasca [el dinero]. Si vos querías ser intendente tenías que mirar para la $3^{16}$, y una vez que te daban el visto bueno [levanta el pulgar], y ganabas, gobernar para la 3. Mientras lo tuvieras [a esos tipos] contentos, nadie te iba a hacer kilombo (Pedro, 56 años, docente).

Cabe destacar que para entonces estos actores económica y políticamente dominantes son numéricamente minoritarios en la creciente población de la Villa que habrá de alcanzar la cuota de 16.000 en 
1991 y la de 24.000 en 2001 . Incluso en momentos en que la complejidad morfológica, estructural y social de la ciudad ya hace tiempo que ha desbordado los límites originales del "balneario" (Tauber, 1998; Noel \& de Abrantes, 2014; Noel, 2014), estos sectores, consagrados como "pioneros" por la literatura local ya mencionada (Noel, 2012), mantendrán en circulación esos tropos que legitiman y naturalizan su posición metonímica en relación con una localidad, en el marco de un repertorio que canoniza en clave moral el proceso de crecimiento económico ligado al comercio de tierras, a la especulación inmobiliaria, a la construcción y al turismo esto es, al modelo de acumulación que permitiera el despegue económico y la canonización de Don Carlos como héroe fundador y campeón fáustico.

La ciudad, sin embargo, se ha transformado de manera radical en el marco de este proceso prolongado de crecimiento. La mayor parte de la población permanente que se ha incorporado a partir de la década del setenta no reside ya en las áreas frecuentadas por la clientela turística, cercana al mar, sino a más de un kilómetro hacia el oeste $^{17}$, y proviene de una extracción social claramente distinta. La evidencia disponible revela un cuadro en el cual sucesivas oleadas de pobladores de bajos recursos fueron estableciéndose sucesivamente en terrenos de la franja oeste de la ciudad, relativamente desprovistos de interés turístico e inmobiliario por su lejanía del mar y por la falta de infraestructura. Se trataba, en buena parte de los casos, de personas o familias de re- giones económicamente deprimidas del país - sobre todo de la propia provincia de Buenos Aires, seguida a cierta distancia por las provincias de las regiones Noroeste y Noreste - y en menor medida del resto de la región, atraídas por la abundancia estacional de puestos de trabajo y por la gran actividad económica de la ciudad durante la temporada. Finalizada la misma, muchos de ellos habían decidido apostar a que la acumulación estival extraordinaria les permitiera un excedente que, sumado a actividades laborales o de subsistencia contracíclicas durante el resto del año $-\mathrm{y}$ que involucran por regla general diversas variedades de cuentapropismo- hiciera posible "aguantar" hasta la temporada siguiente ${ }^{18}$.

A estas migraciones de origen externo, debe agregarse también un proceso de desplazamiento endógeno. Como hemos sugerido en la sección precedente, una vez que Villa Gesell se consolida como localidad turística, el precio de la propiedad inmueble y de la tierra en general se elevan de manera dramática, y aparecen desde entonces afectados por una distorsión perpetua suscitada por la competencia que los residentes de la ciudad se ven forzados a sostener tanto con los especuladores inmobiliarios como con los veraneantes de mayor poder adquisitivo proveniente de las áreas metropolitanas de Argentina que buscan adquirir una propiedad en la Villa. Por estas razones, la adquisición de una propiedad inmueble suele estar vedada a una inmensa mayoría de geselinos —incluso entre las clases medias más o me- pero nadie lo dice: el Viejo no te vendía el terreno si sabia que eras peronista" (Matías, 78 años, albañil jubilado).

${ }^{13}$ Carlos Gesell fallece casi un año exacto después de la obtención de la autonomía, el 6 de junio de 1979.

${ }^{14}$ La evidencia del peso creciente de estos actores puede verse en el hecho de que varios de ellos entablaron disputas legales con "el Viejo" por el control de la ciudad -esto es, por la propiedad de la tierra-en losúltimos años de su existencia (Saccomanno, 1994, pp.145146, 156-157; Gesell, 1983, pp.139-141).

${ }^{15}$ Luego del interregno de siete años supuesto por la dictadura cívico-militar autodenominada con ironía orwelliana "Proceso de Reorganización Nacional" - la más larga y brutal en la convulsionada historia argentina del siglo $X X-$ el 30 de octubre de 1983 tienen lugar las primeras elecciones libresen diez años, y con ellas la renovación - a partir del 10 de diciembre del mismo año-de todas las autoridades nacionales, provinciales y municipales con candidatos electos por el voto popular.

${ }^{16}$ Pedro hace referencia a la Avenida 3, la principal

\section{territarias 35}


arteria comercial de la ciudad, que en Villa Gesell es utilizada con frecuencia como sinécdoque de estos sectores.

${ }^{17}$ La sección oeste de la ciudad está delimitada por una avenida que se extiende en promedio a diez cuadras del litoral atlántico y que lleva el nombre de Boulevard Silvio Gesell. El Boulevard funciona - al menos desde fines de los setenta-como frontera material, simbólica y de clase entre la Villa "turistica" $y$ de los "pioneros", por un lado, y los barrios de sectores populares urbanos que viven en condiciones más precarias por el otro (Noel o de Abrantes, 2014).

${ }^{18}$ Estas tendencias habrian de profundizarse en las décadas sucesivas, en un contexto en que la afluencia migratoria a la ciudad registrará un ritmo constante, en el que resalta en particular el peso de los migrantes de las localidades del interior de la propia provincia de Buenos Aires (Mantero, Bertoni \& Barbini, 1999, p.182), lo que sugiere un efecto de push en un periodo caracterizado por el empobrecimiento de los pequeños productores rurales. A medida que la crisis económica y laboral de mediados de la década (Svampa, 2005) comenzara a hacer sentir sus efectos

territarias 35 nos acomodadas - que no pueden abonar los exorbitantes precios reclamados por una oferta cuyos costos son empujados hacia arriba por el mercado turístico ${ }^{19}$.

El final del siglo XX, por tanto, encuentra a una ciudad que hasta entonces había conseguido presentar como sinónimos crecimiento irrestricto y prosperidad sin límites, atravesada por un proceso de heterogeneización, complejización y fragmentación que coloca a prácticamente la mitad de sus habitantes en condiciones de precariedad habitacional y estructural (Tauber, 1998; Noel \& de Abrantes, 2014). Al menos para ellos, la posibilidad de "vivir de la temporada" se había revelado demasiado pronto como ilusoria.

Así las cosas, la prolongada e indisputada vigencia de los repertorios mediante los cuales la ciudad de Villa Gesell fuera representada hasta entonces y que proveyeran de legitimidad y sustento político a los sectores económicamente más favorecidos que seguían monopolizando la gestión de la cosa pública se enfrentaba al hecho de que esta narrativa épica y triunfalista resulta cada vez menos verosímil para amplias capas de la población que ni fueron protagonistas de este crecimiento ni se beneficiaron de él. Más bien al contrario, aparecían como víctimas de la alta capacidad de legitimación moral y política de un modelo económico fundado en la capacidad de apropiarse durante los dos o tres meses de la temporada estival de una mano de obra ociosa durante el resto del año, y de retener buena parte de los beneficios suscitados por la afluencia de los recursos de los veraneantes metropolitanos. Aun cuando el estatuto autoevidente de este repertorio de legitimación persistía entre aquellos pobladores que arribaran a la ciudad en las primeras décadas de su existencia - y por tanto siguió rindiendo para esos sectores amplios réditos políticos- comenzó rápidamente a perder sustentación sociológica entre los migrantes más recientes, que comenzaron a leerlo como una falaz justificación ideológica de su subordinación laboral, económica y social.

No resulta extraño, por consiguiente, que a medida que el siglo se encaminaba a su consumación — rematada por la crisis política, económica y social de fines de 2001 y comienzos de $2002^{20}$ - comenzaran a hacer su aparición una serie de recursos alternativos que buscaban interpelar primero y reconstruir después el repertorio hasta entonces dominante de la prosperidad triunfante y su particular tonalidad autocelebratoria bajo una luz alternativa y crítica. Este nuevo repertorio moral e identitario - que como veremos también habrá de hallar eventualmente su propia traducción política- procurará disputar los relatos consagrados por quienes durante casi un cuarto de siglo detentaron el control del proceso político de la ciudad y que consiguieron durante mucho tiempo transcribir en forma pacífica y apodíctica su éxito económico en términos de superioridad moral y legitimidad política. 


\section{Los enemigos del alma}

Los que quieren enriquecerse caen en la tentación y se vuelven esclavos de sus muchos deseos. Estos afanes insensatos y dañinos hunden a la gente en la ruina

y en la destrucción.

I Timoteo, VI:9

A ésos hay que taparles la boca, pues trastornan familias enteras, enseñando lo que no deben para obtener ganancias mal habidas.

Tito, I:11

Pues; ¿de qué le sirve al hombre ganar el mundo si pierde su alma? Marcos, VIII:36

La emergencia, circulación y consolidación progresiva de este nueva colección de recursos morales e identitarios que buscará disputar la épica triunfalista de la prosperidad y el progreso se abrirá paso en el marco de una serie de narrativas que, encarnadas en reelaboraciones y movilizaciones sucesivas, conocerán amplia vigencia a lo largo de la década siguiente. Como veremos en breve, este repertorio será movilizado ante todo en el marco de una serie de operaciones de impugnación y crítica moral hacia todo aquello que fuera canonizado en las primeras décadas de historia de la ciudad a través de esa literatura hagiográfico-apologética a la que ya hiciéramos referencia y su núcleo central estará ocupado por una serie de operaciones que expresan una tajante e in- equívoca condena al lucro, el materialismo, la codicia y el economicismo cortoplacista y predatorio que habría caracterizado a esos comerciantes y emprendedores turísticos e inmobiliarios que consiguieron ocupar, sostener y legitimar sus lugares de privilegio en la estructura económica de la ciudad y - en el extremo- al propio impulso que diera origen a la ciudad de Villa Gesell.

Aun cuando sea cierto que la emergencia y circulación de muchos de los recursos de este repertorio pueden remontarse a décadas pasadas, su articulación y movilización creciente confluirá con la consolidación de esas condiciones objetivas que acabamos de señalar, y que le darán un ímpetu y una verosimilitud crecientes a medida que nos aproximamos al cambio de siglo. A su vez, estas condiciones económicas y políticas locales habrán de encontrar resonancias en la circulación más extendida y a escala metropolitana de una serie de repertorios morales ampliamente difundidos entre las clases medias movilizadas en los años inmediatamente posteriores a la ya mencionada "crisis de 2001" (Svampa, 2004; Visacovsky \& Garguin, 2009; Pereyra, Vommaro \& Pérez, 2013), entre las cuales la crítica virulenta y las afectadas retractaciones en torno del neoliberalismo salvaje y del consumismo desenfrenado hegemónicos durante la década precedente, se volverán parte de una nueva rutina retórica en el marco de un paisaje intelectual en el que las referencias a críticos anticapitalistas de amplia resonancia mediática como Naomi Klein, John Holloway, Toni Negri y Michael Hardt o el Subcomandante Marcos reemplazan la de manera generalizada entre los habitantes del pais en general y del Área $\mathrm{Me}$ tropolitana de Buenos Aires en particular, la ciudad registraría también un incremento notorio del volumen de la migración proveniente del $A M B A$ y en particular del conurbano bonaerense (Benseny, 2011)

${ }^{19}$ Al mismo tiempo, el alquiler no suele ser una alternativa demasiado estable para los habitantes de la Villa: en primer lugar, porque como nos señalaran varios de nuestros informantes, muchos propietarios consideran preferible soportar las pérdidas -o al menos el lucro cesante- que implica mantener su propiedad vacia durante el invierno, antes que correr el riesgo de "meter una familia" a la que después no puedan desalojar llegada la temporada, con la consiguiente pérdida de la renta extraordinaria que ello supone. Pero aún cuando no sea del todo imposible conseguir propiedades para alquilar a un precio relativamente bajo durante la mayor parte del año, con la llegada de la temporada los inquilinos se enfrentan a la alternativa de tener que abonar $d u$ rante los meses de verano los montos astronómicos exigidos a los turistas en concepto de alquiler $\rightarrow$ que pueden bien multiplicar por tres, por cuatro o incluso por

territarias 35 
más sus contrapartes invernales-o bien empacar sus cosas y buscar alternativas más modestas fuera de las zonas preferenciales de la ciudad o en condiciones de precariedad estructural que impedirian el alquiler a potenciales veraneantes. Muchos geselinos - y que conste que no estamos hablando aqui (o al menos no exclusivamente) de los pertenecientes a los sectores más desfavorecidos-atraviesan año a año este proceso de trashumancia estacional, $y$ muchos de entre ellos terminan finalmente por desistir de esa inestabilidad perenne $y$ procuran solucionarlas de modo definitivo estableciéndose en las unicas condiciones en las que tienen acceso a la vivienda: en los barrios más modestos y precarios de la franja oeste de la ciudad $y$ en condiciones frecuentemente irregulares. Un análisis reciente de este problema y sus consecuencias, acompañada de una serie de propuestas en torno del mismo pueden encontrarse en el sitio del Observatorio de Políticas Públicas de Villa Gesell, en http://oppgesell.com.ar/(Consultado el 31 de enero de 2015)

20 "La crisis de 2001" o "Diciembre de 2001" hace referencia en Argentina a una serie de eventos que configuraron la mayor crisis institucional, politica, social y económica de las úl-

territarios 35 precedente popularidad de Francis Fukuyama, Guy Sorman o el Manual del Perfecto Idiota Latinoamericano.

$\mathrm{Al}$ igual que su predecesor inmediato, este nuevo repertorio también será en gran medida articulado y puesto en circulación por medio de un dispositivo literario ${ }^{21}$. En este marco, el primer cuestionamiento al relativo consenso previo en torno de las implicaciones morales de la prosperidad geselina los encontramos en El Alma Perdida de Gesell, un texto escrito y editado en 2002 por Juan Jesús Oviedo, prolífico escritor, cronista e intelectual local establecido en la Villa desde fines de los setenta. Como ya hemos señalado en otra parte, el texto de Oviedo se inscribe en un movimiento relativamente tardío de recuperación de un momento histórico central para la ciudad, pero hasta entonces elidido en las narrativas consagradas por la prolífica literatura local la primavera contracultural que hiciera eclosión en la ciudad en las décadas del sesenta y del setenta. Como lo sugiere desde su título, el texto de Oviedo- escrito cuando la recuperación identitaria de esta coyuntura está ya avanzada - invita a pensar el 'momento hippie' como expresión de la Villa auténtica, de su 'alma' singular, de su fibra más íntima, y de un ímpetu libertario, naturalista y espontáneo que habría dado origen al irreverente, auténtico y singular espíritu de la ciudad (Oviedo, 2002).

Movilizando recursos retóricos análogos a los de las 'historias de pioneros', Oviedo propondrá en este texto un repertorio moral-identitario alternativo en el que las virtudes fundamentales ya no son las de la ética protestante adjudicadas a "Don Carlos" y a los pioneros en la literatura canónica, sino otras ligadas a valores en muchos casos contrapuestos o incluso incompatibles con las precedentes: la "libertad", el "amor a la naturaleza", la "espontaneidad", la "creación", el "espíritu de rebeldía", el "anticonvencionalismo", la "autenticidad". Los demiurgos de este nuevo paraíso ya no son emprendedores fáusticos que transforman y reconstruyen el paisaje a su imagen y semejanza, doblegando manu militari una naturaleza indómita y rebelde a su titánica voluntad, sino amorales héroes "homéricos", "seres sensitivos, con valores e instintividad, seres creadores, reformuladores y revolucionarios" (Oviedo, 2002, p. 25). Más aún, la incompatibilidad entre las virtudes de estos nuevos héroes y las de los antiguos lleva a Oviedo a una impugnación de la supuesta pureza moral de los motivos de estos: los "pioneros", afirma Oviedo en un gesto que como veremos habrá de ampliarse en textos sucesivos, no pueden reclamar papel alguno en la construcción del "alma" de la ciudad, ya que:

[...] no fueron tales por su espíritu aventurero, sino por su ímpetu comercial. Hallar una fuente de trabajo o un posible enriquecimiento rápido fueron motivos para acudir a este lugar $(.).[\mathrm{y}]$ una visión financiera no implica necesariamente la creación de una determinada identidad (Oviedo, 2002, p. 47).

Como puede verse, en este punto el texto de Oviedo expresa una tesis audaz: la de que Villa Gesell, una empresa turístico- 
comercial iniciada por un entrepeneur y secundada por un conjunto de inversores de riesgo, habría sido un "cuerpo sin alma" (Oviedo, 2002, pp. 24, 48-49) hasta tanto no recibió el hálito fecundador de esa suerte de Dionisos colectivo, advenido desde la metrópoli y encarnado en los jóvenes rebeldes e irreverentes de mediados de los sesenta, su ethos y sus prácticas. Solo una vez que ese cuerpo estéril, surgido de un banal espíritu de lucro, fue fecundado por parte de un espíritu "auténtico" y "honesto" encarnado en esos Übermenschen nietzscheanos habría nacido "la Villa". Ciertamente, como nos lo recuerda el autor con insistencia, ese espíritu fue finalmente derrotado por el espíritu de lucro y la especulación cortoplacista y por ello ese crecimiento sucesivo del cuerpo de la Villa que hará de ella una "ciudad" - desplegado en las dos décadas sucesivas, la del setenta y la del ochentasepultó finalmente su alma única y singular.

Sin embargo, esta impugnación original presentada como correlato crítico de una afirmación identitaria encontrará una articulación más explícita, una sistematización más completa y una defensa más elocuente en dos textos sucesivos surgidos de la misma pluma: No todo lo que reluce es oro (primera y segunda Parte) (Oviedo, 2006 y 2007) y Balneario Rico, Pueblo Pobre (Oviedo, 2009). En ellos, el autor despliega, reelabora y amplía las imputaciones iniciales acerca del papel deletéreo que el materialismo cortoplacista, la especulación inmobiliaria y la voracidad económica habrían tenido en la disolución del ethos singular y virtuoso suscitado por ese momento mágico de finales de los sesenta y comienzos de los setenta en el que Villa Gesell se transfiguró en "La Villa”. En este empeño y a lo largo de estos dos textos más recientes Oviedo desafiará, desmitificará e impugnará con vehemencia creciente la visión romántica, fáustica y épica de la historia de la ciudad sobre la cual se montó durante más de tres décadas la legitimidad moral de sus principales actores políticos y económicos, procurando desacralizar estos relatos mediante la apelación a una serie de motivaciones menos heroicas y más mezquinas para sus protagonistas, que subrayan su putativo y prosaico carácter comercial, especulativo, egoísta e interesado y - en el límite - pernicioso para el desarrollo pasado y futuro de la ciudad.

No todo lo que reluce es oro... subtitulado Reflexiones sobre el pasado, el presente $y$ el futuro de algunos balnearios de la costa atlántica argentina y publicado en dos partes en 2006 y 2007, es presentada por su autor como una obra exploratoria que busca plantear a título interrogativo y en clave comparada algunos de los principales desafíos a los que se enfrentarían las localidades de la costa Atlántica bonaerense en relación con su desarrollo integral, y en particular los putativos límites de la estrategia balnearia para su crecimiento sostenido. En este proceso, Oviedo nos enfrenta por vez primera en letras de molde con una oposición entre "balneario" y "pueblo", que es inscripta en términos de la estacionalidad constitutiva configurada por la actividad turística (Oviedo, 2006). timas décadas, y que representaron la eclosión de las contradicciones implicitas en una década de políticas neoliberalesinspiradasen el denominado "Consenso de Washington" (qv. Pereyra, Vommaro \& Pérez, 2013).

${ }^{21}$ Como hemos mostrado en otra parte (Noel, 2012) la principal estrategia de difusión de repertorios identitarios y morales en la ciudad de Villa Gesell está concentrada en la producción, la circulación y la reproducción por diversas vías de una serie de textos canónicos sobre la ciudad, su historia y su naturaleza. La aparición de productos literarios en este registro identitario-moral, en consecuencia, marca con suma precisión los momentos en los cuales los principales repertorios de identificación se vuelven disponibles. En este sentido, la obra de Oviedo - a la cual haremos amplia referencia - encarna de manera eminente la consolidación de este nuevo repertorio de impugnación moral que intentamos caracterizar a lo largo del presente paper.

territarias 35

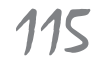


${ }^{22}$ La localidad de Pinamar, próspero balneario de élite fundado en 1941 por una sociedad anónima encabezada por el arquitecto Jorge Bunge y Valeria Guerrero (Oviedo, 2008, p.95ss), se encuentra a $21 \mathrm{~km}$ al norte de Villa Gesell y es cabecera del municipio homónimo. Pinamar es objeto permanente entre una serie de caracterizaciones que los geselinos hacen de sí mismos $y$ de su ciudad por oposición a su vecina más cercana, y que se expresan en una serie de contrastes sociales y morales que oponen su carácter putativamente "frivolo", "aristocrático", "elitista” y "superficial" por oposición a una Villa Gesell "genuina", "ignalitaria", "informal" $y$ "auténtica”. La caracterización de Oviedo en gran medida recoge y presenta de manera sistemática estas oposiciones.

\section{territarias 35}

Si bien la primera parte de la obra es principalmente descriptiva, concentrándose particularmente en un análisis comparativo de los desarrollos de Villa Gesell y su localidad vecina, $\operatorname{Pinamar}^{22}$ y en menor medida de otras localidades de la costa atlántica bonaerense; la segunda asume desde el comienzo un tono más explícitamente crítico, y su argumento se abre con una caracterización del proceso de devenir histórico de estas ciudades como "crecimiento sin desarrollo" (Oviedo, 2007, p. $12 \mathrm{ss})$. Las razones detrás de este diagnóstico implican la percepción de que cualquier posibilidad original de desarrollo de estas localidades habría sido paralizado en forma temprana por:

[...] el hecho de tener en cuenta una sola visión de las fuerzas productivas [...]: la concepción del crecimiento como un hecho basado en el progreso del vigor comercial. Y tal manera de pensar el progreso induciría a una visión unidimensional, la de entender a estos lugares solo desde la mera condición de lucro, visión cautivadora de las sociedades locales, por la cual estas nacerán y crecerán satelizadas bajo tal concepción (Oviedo, 2007, p. 13, subrayados del autor).

Así, según Oviedo, estas ciudades estarían marcadas desde su concepción misma por el pecado original de "la renta y la búsqueda de la riqueza (...) expresión de una preconcebida concepción, la comercial" (Oviedo, 2007. p. 17), que las hicieron surgir primero y crecer después de manera inorgánica y desordenada "a partir del fe- nómeno de la renta y de la venta (...) bajo (...) condiciones tales como los loteos, las ventas de terrenos y la correspondiente edificación" de manera tal que "su impulso supremo $(. .$.$) tuvo un a priori determinado$ por un mercado inmobiliario" (Oviedo, 2007, pp. 19-20). Aun así, el autor se encarga de aclarar que en los comienzos de este proceso el primum movens del lucro no fue necesariamente perjudicial, en la medida en que el crecimiento original del "balneario" subsidió al de la "ciudad". Sin embargo, a partir de cierto momento este círculo virtuoso se habría roto, produciéndose un desequilibrio que habría tenido como consecuencia que esa ciudad, otrora subsidiaria del balneario, "lo desborde", con lo cual el modelo de crecimiento turístico pierde sustentación y entra en pérdida (Oviedo, 2007). Como consecuencia, el autor concluye que aunque el turismo como generador de desarrollo hace tiempo que ha encontrado su límite (Oviedo, 2007), las ciudades balnearias de la costa atlántica bonaerense parecen no haberse percatado de ello, obcecadas por un atavismo ciego y suicida que bloquea la búsqueda de potenciales alternativas.

La preocupación terapéutica y el tono reflexivo y mayéutico que caracterizan a Todo lo que reluce... serán reemplazados en su sucesor -Balneario rico, pueblo pobre. Una mirada critica a los centros turísticos de la costa bonaerense- por una precisión diagnóstica y una sorda indignación moral, que transforma en certezas muchos de los interrogantes del libro precedente, $\mathrm{y}$ a cuyo furor crítico no se sustraen ni siquiera las 
obras anteriores del propio autor. Como puede advertirse, Balneario rico, pueblo pobre consagra y cristaliza desde su título mismo una oposición que será reconstruida con prolijidad levistraussiana al interior del texto mediante una serie de oposiciones al menos parcialmente homólogas que incluyen de modo eminente las de: "balneario/pueblo, verano/invierno, turista/ residente, calle peatonal/barrio periférico, servicios/ausencia de servicios, edificios/ villas” (Oviedo, 2009, p. 12).

Más importante aún, el eje central del argumento presenta la preocupación original del libro precedente acerca de la omnipresencia pasada y presente de un "sentido de la renta" y de "la ganancia" que "al terminar por imponerse, se constituye a posteriori en una barrera para el desarrollo social de la población costera" (Oviedo, 2009, p. 33), pero desplegándolo ahora en el formato de una denuncia caracterizada en clave de cierta vulgata marxista. Así, Oviedo afirma que la visión vernácula presentada por las múltiples 'historias de pioneros' que procuran reconstruir los orígenes de las diversas localidades balnearias (y entre las cuales la de Villa Gesell no es más que un caso particular) (Oviedo, 2009, p. 13), no son sino la máscara mitológica de una falsa conciencia que busca - y peor aún: consigue - encubrir una realidad subterránea más fundamental y menos halagadora: el hecho de que los balnearios surgieron con un fin estricto de lucro "de un pragmatismo económico basado en servicios y pequeños negocios que son el eje económico del lugar" (Oviedo, 2009, p. 15) generando "un tipo de sociedad precarizada" (Oviedo, 2009, p. 33). Tales 'mitos de origen', continua Oviedo, proponen y postulan una solidaridad ficticia, inverosímil y a fortiori estructuralmente imposible entre los emprendedores-fundadores-capitalistas - a la que se suman luego los turistasburgueses - y su mano de obra proletaria, mistificación que encubre con un manto de pretendida armonía las auténticas relaciones socioeconómicas de explotación y dominación que entre ellos se establecen y que configuran la infraestructura del negocio turístico (Oviedo, 2009). A su vez, en la medida en que esta falsa conciencia mitológica permanece vigente a partir de su consolidación hegemónica ulterior en los cánones locales, su despliegue permite justificar, legitimar y prolongar una situación de explotación perenne, en la cual una serie de patrones-propietarios viven, prosperan y disfrutan de la ciudad y sus beneficios a expensas de las grandes masas de trabajadores proletarizados, precarizados y no calificados exigidos por la actividad turística — producto por su parte de un alienante y alienado ocio burgués (Sebreli, 1970) - y cuya prolongación en el tiempo impide, como hemos visto ya en el libro precedente, cualquier desarrollo genuino a futuro.

Más aún, si en el libro precedente (Oviedo, 2006) el propio Carlos Gesell - aún cuando sometido a una primera operación de desmitificación en clave euhemerista - era todavía presentado como una figura cuya concepción y cuyo designio otorgaron cierta singularidad y ciertas ventajas comparativas a Villa Gesell respec- territarias 35 
23 'Teoría del derrame' es la traducción local e hiperbólica popularizada en la Argentina neoliberal de los noventa de lo que en la literatura anglosajona se conoce con el nombre más modesto de 'trickle-down effect' [efecto de goteo] y que implica la afirmación de que los beneficios extraordinarios de los sectores más prósperos del mercado terminarian descendiendo por vía de 'goteo' sobre los sectores más desfavorecidos.

${ }^{24}$ Cabe señalar que este cuadro presentado por Oviedo y que reconstruye un equilibrio pretérito en el cual la ciudad crecía impulsada por un círculo virtuoso en el cual la generación de riqueza durante la temporada le permitía planear en forma controlada durante "el invierno" sin discontinuidades ni privaciones está ampliamente extendida entre los residentes de larga data de la ciudad, particularmente entre quienes tienen una posición económica desahogada. La cronología del colapso de este modelo de sustentabilidad local varía bastante entre nuestros informantes: si bien muchos comparten la posición de Oviedo y colocan el punto de inflexión en la década del setenta, son varios los que discrepan de esa adjudicación tem-

territarios 35 to de sus localidades vecinas (en particular en relación con la frívola Pinamar), en esta ocasión le caben las generales de la ley y las referencias a su persona o a sus textos lo muestran como un mezquino especulador inmobiliario, una suerte de pequeño tendero con sueños de vuelo bajo, al punto que Oviedo, en un despliegue de furor iconoclasta, lo caracteriza como "el empresario Carlos Gesell” (Oviedo, 2009, p. 62).

$\mathrm{Al}$ mismo tiempo, el texto afirma que las románticas historias de pioneros proveerían a su vez una de las principales coartadas de los emprendedores turísticos y sus aliados políticos, en una suerte de versión local de la 'teoría del derrame' ${ }^{23}$ : la de que el crecimiento turístico sería la base del ulterior desarrollo de estas ciudades, lo cual no sería en el fondo más que una forma de proteger los intereses de clase de los principales propietarios y comerciantes de la ciudad, y el sometimiento de los proletarios que constituyen la mano de obra estacional de aquéllos:

Esta mentalidad oculta al balneario como construcción burguesa, hecho por y para esa clase, por lo tanto nacido como espacio cautivo de apellidos que tomaron posesión de los medios de producción - en este caso servicios - a través de hoteles, restaurantes, supermercados, paradores y balnearios en la playa, accionistas en cooperadoras y responsables de que la sociedad en su conjunto gire satelizada en el único interés vigente que son los intereses del balneario y de los suyos (Oviedo, 2009, p. 33ss, subrayados del autor).
Como ya se sabe, continúa el autor, el motor ideológico de este mito sería el concepto de progreso, reducido a una dimensión unidimensional y cuantitativa "en términos de crecimiento urbano - entiéndase edificación horizontal y condiciones para que se alberguen mayor cantidad de turistas" (Oviedo, 2009, p. 78) y desprovisto por tanto de toda racionalidad estratégica. De esta manera, en estas localidades:

[...] el crecimiento obedeció a una ley —la del mercado- a quién rigió e impulsó las acciones con la venta de lotes, más la construcción y venta de lo construido por el cual el estatus de ciudad implicó la mera condición acumulativa” de casas, edificios o expansión edilicia de a parches. Ese emparchamiento [sic] no es planificación, sino mera construcción sujeta al eje de la renta (Oviedo, 2009. pp. 82-83).

Aun así, el autor se apresura a señalar - reproduciendo casi verbatim la reserva expresada en el texto precedente- que no siempre los efectos de este proceso fueron deletéreos, y que hasta cierto punto en la historia de estas localidades habría sido posible pensar sin contradicción ni disimulo en un crecimiento virtuoso que estimulara el desarrollo (Oviedo, 2009). Sin embargo, como ya hemos visto, en determinado momento ese equilibro se pierde y empiezan a aparecer en consecuencia los fenómenos de pauperización, heterogeneización y desarrollo desigual que configuran el perfil de "las dos ciudades" y su progresiva natura- 
lización ideológica en la conciencia de sus habitantes (Oviedo, 2009, p. 50) ${ }^{24}$.

Asimismo, el turismo es caracterizado a lo largo del texto en términos de una actividad depredatoria, no solo porque los putativos beneficios y mejoras relativas al mejoramiento, mantenimiento y expansión de la infraestructura turística no tendrían impacto alguno sobre la inmensa mayoría de los residentes del "pueblo" (Oviedo, 2009 ), sino porque la visión que busca hacer de la actividad turística la base de un potencial modelo de desarrollo encubre una serie de consecuencias deletéreas e inherentes a la propia naturaleza alienante de esa actividad. La crítica guénoniana de Oviedo coloca como raíz de esta múltiple alienación a la ya mencionada concepción unidimensional,

[...] del éxito como cantidad a la que tuvieron que subordinarse todos, a las estadísticas, a lo mensurable" a partir de la cual "se incorporó sin crítica alguna ese principio utilitario, tal como sucede en la promoción del destino turístico, aunque la misma sea alienante para el lugar (Oviedo, 2009. p. 136).

A esto cabe agregar la alienación adicional producida por un proceso de escenificación falaz y artificioso que implica un ocultamiento selectivo de la población y de la trama urbana, la ya mencionada generación de empleo precarizado y poco calificado, el carácter improvisado y cortoplacista de una parte notoria de los emprendimientos comerciales y económicos de temporada y el "aturdimiento" persistente que esta actividad genera en muchos de sus habitantes de tiempo completo (Oviedo, 2009).

Ahora bien, como ya tuviéramos ocasión de señalar, este argumento que Oviedo despliega en forma extensiva y en su versión más sistemática y radicalizada en las dos obras que acabamos de reseñar está lejos de representar una posición idiosincrásica del autor por más que la singularidad sí se aplique a su marco retórico y a su inspiración teórico-moral. Más bien al contrario; recoge de manera particularmente exhaustiva una serie de recursos que, como hemos visto, han conocido particular vigencia en la Villa Gesell del cambio de siglo.

Algunas veces, estos recursos aparecen movilizados por nuestros informantes en el marco de una caracterización descriptiva en la que solo de manera muy elíptica puede reconocerse una cierta clase de crítica moral:

[...] esta es una comunidad muy diferente, porque es una comunidad comercial, una comunidad que ha tenido otro origen $[\ldots]$ nosotros con [mis amigas] siempre comentamos que Gesell es [...] una comunidad un poco fenicia... y digo 'fenicia' [en el sentido histórico de la palabra, ¿no?] navegantes, comerciantes, que iban y venían, que lo que querían era una factoría, e iban y venían [y] hasta ahí nomás [...] me parece que es una comunidad [a la] que le falta raíces... y eso no sólo tiene que ver con poco o mucho tiempo de creación, sino también con una identidad y una característica propia, en la que cuesta producir arraigo (Martha, 51 años, docente de escuela media). poral y colocan el quiebre a mediados de los ochenta, a principios o mediados de los noventa o incluso en el más reciente cambio de signo politico (cf. infra). Como bemos ya sugerido, aunque la perspectiva de "vivir de la temporada" forme parte del horizonte aspiracional de buena parte de los geselinos, y aunque la misma sea predicada con frecuencia como una posibilidad real "basta bace no tanto tiempo" para la mayor parte de los geselinos 'respetables', tenemos razones para creer que contrariamente a ese supuesto, esa expectativa no fue de becho nunca verosimil más que para una infima minoría de los sectores mejor acomodados de la ciudad y que quienes afirman lo contrario no bacen más que extender indebidamente la singularidad que le da su posición excepcional a una mayoría de la población que nunca gozo de ella.

territorias 35

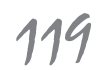


${ }^{25}$ Unión de Comercio e Industria.

territarias 35 120
Sin embargo, no es infrecuente que estas caracterizaciones aparezcan explícitamente enunciadas en el marco de esa oposición crítica que ya encontráramos en $\mathrm{El}$ Alma Pérdida de Gesell. Así nos lo presenta Guillermo, un contemporáneo de Oviedo:

[A ver] siempre hubo dos villas, también en la historia: la de los fenicios y la de los soñadores. Yo una vez hice una nota, en un semanario que tuve... 'Fenicio' era [el título de] la nota. Como decíamos [recién] estos tipos vinieron a... muchos vinieron a escaparse, [pero] muchos vinieron a hacer guita y no les importaba demasiado [dónde y cómo: vinieron como podrían haber ido a cualquier lado]. ¡[Así son] los fenicios! Vos rascás y el fenicio, en el fondo dice 'Vamos a hacer negocios'. No hay otra alternativa entonces... y la de los soñadores, y ya la [Villa] de los soñadores se ha ido terminando o han ido entendiendo que la felicidad pasa por ser fenicio y no por ser soñador. No tiene nada que ver esa Villa [con la de antes], porque la villa no... los lugares no son entornos ni contornos sino gente, si la gente acá no pisa más no importa si vos tenés bosque, tenés mar o tenés dunas inmensas... entonces al modificarse [las circunstancias]... por ahí los pibes de estos chicos [ie. los soñadores] son diferentes, se meten en otro engranaje [más fenicio] (Guillermo, 61 años, periodista).

También aparecen con frecuencia las referencias explícitas al control del poder político que estos actores habrían obtenido y mantenido a partir de la doble coyuntura representada por la obtención de la autonomía y la muerte de Carlos Gesell. La conversión de capital económico en poder político que estos sectores habrían conseguido asegurar y legitimar sobre la base de esa equivalencia entre éxito personal, prosperidad de la ciudad y superioridad moral - se nos dice- los habría colocado en una posición que les permitió movilizarlo para la defensa de sus propios intereses mezquinos y en correlativo detrimento del bien común que debería constituir el objetivo de toda política rectamente entendida.

Fernando, un habitante de larga data de la ciudad, narra la transición hacia la autonomía y la sucesión entre las dos primeras administraciones municipales - que tuvieron lugar en el marco del gobierno de facto de la dictadura cívico-militar- como una puja en la cual los poderes fácticos disputan -y finalmente consiguen- el control del poder político de la ciudad:

[Lo que hay que tener en cuenta es que antes de la Autonomía] acá había mucha inorganicidad [sic] [...] Había [un delegado] [...] [la Municipalidad lo había puesto] [...] pero en el poder concreto lo manejaba lo que es la $\mathrm{UCI}^{25}$ ahora, que antes era la agrupación donde estaban todos los tipos pesados, [y] manejaban esto como se les cantaban las bolas, [tenían un] poder absoluto para hacer negocios, de todo.

[Y como me contó después un muchacho amigo] cuando los milicos lo ponen a Pidal ${ }^{26}$... Pidal llamó a este muchacho, que me contó esta historia, lo llama, los atiende 
[a los representantes de la Agrupación de Comerciantes] y estaban contentos, porque este les dice 'Ustedes son el poder acá'. [Pero Pidal lo interrumpe y les dice:] 'No. La idea es corregir [eso]. El poder ahora es este' dijo Pidal, tiro el fierro [el arma] sobre la mesa 'acá se acabó, acá ahora mando yo, así que listo, olvídense'. Lo empezó a manejar él [...] Hay un gran debate acá entre el Pidal funcionario que cumplió pautas [y las hizo cumplir] y el Pidal como representante de la dictadura, pero acá fue útil Pidal porque puso orden y le dio [forma] a esto... sino hubiera sido un quilombo. Porque estos tipos de acá manejaban el poder de forma discrecional. [Por eso] si vos hablás con los viejos te van a decir que muchos lo querían y bueno, [también] después por eso le tenían mucho odio, por eso acá - yo tampoco quiero decir los nombres pero están todos vivos, salvo uno-cuando Pidal queda viudo, se juntó con una mujer acá no sé si se casó o no, pero murió de cáncer, Pidal. Y estos representantes de la Cámara de Comercio de ese momento y algunos empresarios de medios de comunicación de hoy, descorcharon botellas y brindaron por la muerte de Pidal.

Después este grupo [de Comerciantes] se consolidó. Cuando muere Pidal el contacto político hace que lo sucediera Federico Schmidt, Freddy Schmidt - que tenía un corralón acá... (...) pero ahí se consolida todo este poder, porque (...) cuando viene Freddy Schmidt se consolida otra vez el modelo de control comercial y el crecimiento desmedido de cuestiones [especulativas], porque ahí aprovechan para hacer mucha especulación inmobiliaria. Ahí [...] logran [...] modificar en La Plata [la zonificación] y logran hacer una traza de lo que fue la Costanera. Entonces ahí se abren un montón de especulaciones [inmobiliarias]. Y con ese poder que tenían aprovecharon para apretar al Viejo Gesell. Ahí crecieron desmesuradamente en la cuestión económica porque tenían las dos cuestiones, tenían el poder económico [y] el poder para manejar cuestiones que tenían que ver con la sucesión [del Viejo]. Hicieron lo que quisieron, porque había cierto descontrol administrativo. Pero todos los papeles de lo que era catastro, el registro de quién tenía qué cosa, tenían todos los datos, e hicieron lo que quisieron. Tenían todo a su disposición. Así que si había terrenos que no pagaban impuestos, ellos [los apretaban] o pagaban los impuestos [y los adquirían por usucapión], hicieron moratorias [para los amigos], fue un descontrol. [La gestión] de Freddy Schmidt fue la consolidación de eso (Fernando, 73 años, jubilado).

\section{Coda: el Repertorio de Impugnación como Nueva Fuente de Legitimación Política}

Como puede verse a partir de estos ejemplos particularmente ilustrativos, los recursos morales fundados en una impugnación al espíritu de lucro y el materialismo ramplón - encarnación local de una serie de tropos que encuentran su fundamento no solo en la ya mencionada crítica postneoliberal al desenfadado y frívolo materialismo de los noventa, sino también en la perenne sospecha moderna hacia el dinero y sus
${ }^{26}$ El Comisario Pidal, un policía cuya trayectoria como represor antecede incluso a los años de plomo de la dictadura cívico-militar fue designado por el gobierno de facto de la provincia de Buenos Aires como primer intendente de la ciudad una vez concedida la autonomía municipal. A su muerte Pidal fue sucedido por un segundo intendente de facto: Federico Schmidt, ungido - como afirma Fernando-con el placet de los poderes fácticos de la ciudad. territorios 35

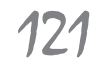


${ }^{27}$ Aun así, el despliegue más radical de este repertorio y de sus principales recursos no tendrá lugar en la propia ciudad de Villa Gesell, sino unos cinco kilómetros al sur de su limite meridional, donde a partir de los comienzos del nuevo siglo Mar de las Pampas, una localidad que hasta entonces se reducía a un punto en el mapa $\rightarrow$ durante mucho tiempo ni siquiera a esoregistrará un crecimiento explosivo que reproduce en forma ampliada y acelerada el sufrido por la Villa en los tempranos setenta, pero ante el cual sus pobladores responderán activamente movilizándose sobre la base de lo que consideran una obligación de evitar la repetición de este precedente funesto. La configuración y el desarrollo de ese proceso puede consultarse en Noel (2011) y Noel (2013a).

\section{territarias 35}

efectos potencialmente disolventes del lazo social (Wilkis, 2013) - se encuentran sumamente presentes en varias de las operaciones críticas que varios de nuestros interlocutores realizaran a ciertas formas de posicionarse en y ante la Villa de fines de siglo $^{27}$. Ante el panorama de una ciudad que parece haber desbordado social, económica y políticamente los límites que el proyecto inicial de Carlos Gesell le impusiera, así como las posibilidades de los principales actores políticos y económicos para sostener y legitimar su hegemonía de otrora mediante el recurso a una serie de repertorios identitarios y morales consolidados en las primeras décadas de existencia de la ciudad, y consagrados en su literatura canónica, sus posiciones comienzan a ser impugnadas mediante un nuevo lenguaje, que recoge su potencia de una serie de repertorios locales y metropolitanos solidariamente enhebrados que - como una suerte de piedra filosofal en reverso - transfiguran las virtudes doradas de antaño, fuente de crecimiento, progreso y orgullo en una ciudad que se hizo a sí misma de la nada, en un prosaico egoísmo de tendero que, magnificado por el éxito a expensas del esfuerzo ajeno, prolonga un sometimiento político moral y colectivo que se postula como contrario al verdadero espíritu de la Villa.

Resulta interesante señalar que aunque este repertorio se encuentra en principio restringido a una minoría articulada, pero poco representativa, que lo pone y lo mantiene en circulación más que nada en una suerte de trinchera defensiva respecto de lo que consideran un desvío y un callejón sin salida - tanto económico como político, tanto social como moral- en la vida colectiva de la ciudad, muy pronto sus recursos habrán de ser puestos en circulación —al igual que lo que sucediera con los de su predecesor inmediato- en el marco de un proceso de legitimación política. En efecto, las elecciones municipales de 2007 habrán de consagrar por primera vez en la historia de la ciudad a un intendente que no ha surgido de entre las filas de esa élite local de comerciantes, empresarios y profesionales locales, y que sin lugar a dudas tampoco ha sido ungido por ellos (Noel, 2014a). Como puede suponerse, las razones de su advenimiento al ejecutivo municipal en ningún caso pueden reducirse - ni directa ni indirectamente- a la emergencia del repertorio de impugnación que hemos estado reconstruyendo: son, en cualquier caso, mucho más prosaicas y deben buscarse ante nada en una combinación entre los errores y la torpeza política de su predecesor y el apoyo político y económico considerable que el candidato vencedor recibiera de los gobiernos nacional y provincial. Mas como quiera que sea lo cierto es que una vez instalado en el palacio municipal, y enfrentado a una serie de impugnaciones que buscan socavar su capacidad de representar a la ciudad -en el doble sentido del término, el sociológico y el político- el nuevo intendente echará mano con liberalidad de este nuevo repertorio, presentando su gestión como una "refundación" de la ciudad que busca arrebatársela de las manos a quienes solo pensaron $-\mathrm{y}$ siguen pensando- en sus réditos personales, para reconstruirla 
en beneficio del bien común. De allí en adelante, consolidada esta operación retórico-política, el nuevo repertorio recibirá un ímpetu adicional que lo pondrá definitivamente en circulación, en coexistencia tensa e irregular con su predecesor otrora hegemónico, en el marco de una disputa que - ahora sí - parece hacer cierta justicia a la complejidad morfológica y moral que este antiguo emprendimiento turístico, ahora devenido ciudad intermedia, adquiriera en las últimas tres décadas.

Más allá de la inevitable especificidad del caso etnográfico y las particularidades locales que el proceso adquiere para el escenario geselino, creemos que la transición que acabamos de reconstruir en perspectiva histórica da cuenta cabal del modo en que se enlazan la morfología social de una ciudad (Noel \& de Abrantes, 2014), los repertorios de identificación moral que diversos emprendedores producen sobre ella y sus modalidades de circulación (Noel, 2013b), las formas en que estos se consolidan en formaciones mitopolíticas (Miguel, 1998) y son movilizados en el marco de procesos de legitimación (Douglas, 1986) y, por último, las precondiciones sociológicas de su verosimilitud en diversos colectivos sociales. Como esperamos haber dejado en claro a partir del presente trabajo, difícilmente podamos dar cuenta de los procesos de transición política de esta clase sin prestar atención a los modos complejos y recíprocos en los cuales estas distintas dimensiones - morfológicas y sociológicas, identitarias y morales - interactúan en el transcurso del devenir histórico.

\section{Agradecimientos}

El presente trabajo forma parte del proyecto de investigación "Fronteras Morales, Fronteras Sociales: Las Moralidades en el Proceso de Articulación de Identidades, Alteridades y Conflictos en Condiciones de Fragmentación Social" (CONICET) y contó con financiamiento del Proyecto de Investigación Plurianual "Sociología del dinero: evaluaciones monetarias y jerarquías sociales" dirigido por el Dr. Ariel Wilkis en el IDAES/UNSAM. Quisiéramos agradecer por sus valiosos aportes e intuiciones a nuestros colegas del proyecto, en particular a Ariel Wilkis, y Alexandre Roig, así como a nuestros interlocutores en el campo, tanto a aquellos a quienes por razones de confidencialidad no podemos mencionar por su nombre como a quienes sí y entre los que se cuentan Elisa Capucci, Mónica García, Manolo García, Santiago Massafra, Eduardo Minervino, Juan Oviedo, Ignacio Paganini, Guadalupe Pagliano, Juan Ignacio Provéndola, Irina Rodríguez y Deby Tescione. Todos ellos -innominados incluidos - fueron infinitamente generosos para con nosotros y para con nuestra investigación, y nos pusieron en la pista de varios de los argumentos que estructuran el presente texto. Agradecemos también a Lucía de Abrantes y a Jimena Ramírez Casas sus comentarios a una versión preliminar del presente texto. territarios 35

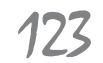




\section{Referencias}

AAVV (2008). Autonomía Municipal de Villa Gesell. Historia y Documentos. Villa Gesell: Municipalidad de Villa Gesell.

Benseny, G. (2011). La Valorización Turística de la Costa Atlántica Bonaerense. El Surgimiento de Villa Gesell (Argentina). Ponencia Presentada en el Encuentro Internacional en Turismo. Mar del Plata. 21 - 23 de Septiembre de 2011.

Berman, M. (1988). Todo lo Sólido se Desvanece en el Aire. La Experiencia de la Modernidad. Buenos Aires: Siglo XXI.

Douglas, M. (1986). Cómo Piensan las Instituciones. Madrid: Alianza.

García, M. \& Palavecino. C. (2006). Las Fundaciones de Villa Gesell. Villa Gesell: Edición de autor.

Gesell, R. (1983). Carlos Idaho Gesell. Su Vida. Villa Gesell: Edición de autor.

Guber, R. (2003). Identidad Social Villera. En M. Boivin, A. Rosato \& V. Arribas. Constructores de Otredad (pp. 115125). Buenos Aires: Antropofagia.

Guía Turística y Comercial de Villa Gesell (1959) s.n.b.

Güiraldes, R. (1955) [1926]. Don Segundo Sombra. Buenos Aires: Losada.

Keynes, M. (1997) [1943]. Teoría General de la Ocupación. El Interés y el Dinero. México: FCE.

Miguel, L. F. (1998). Em Torno do Conceito de Mito Político. En Dados. 41(3) Doi: dx.doi.org/10.1590/S001 152581998000300005

territarias 35

Noel, G. (2011). Guardianes del Paraíso. Génesis y Genealogía de una Identidad
Colectiva en Mar de las Pampas. Provincia de Buenos Aires. Revista del Museo de Antropología, IV, 211-226

Noel, G. (2012). Historias de Pioneros. Configuración y Surgimiento de un Repertorio Histórico-Identitario en la Costa Atlántica Bonaerense. Atek Na, 2, 165-205.

Noel, G. (2013a). De la Ciudad Slow al 'Vivir sin Prisa': Algunos Encuentros. Desencuentros y Disputas en torno del Movimiento Slow en una Localidad Balnearia de la Costa Atlántica Argentina. Revista Contenido, 3(1),18-42.

Noel, G. (2013b). De los Códigos a los Repertorios: Algunos Atavismos Persistentes Acerca de la Cultura y una Propuesta de Reformulación. Revista Latinoamericana de Metodología de las Ciencias Sociales, 3(2). Recuperado el 16 de junio de 2016, de: http://www. relmecs.fahce.unlp. edu.ar/article/ view/relmecs_v03n02a04

Noel, G. (Mayo de 2014a). La Autoctonía como Garantía Moral de la Política: Retóricas de la Legitimidad en una Ciudad Intermedia de la Provincia de Buenos Aires (Argentina). Papeles de Trabajo, 14.

Noel, G. (Julio de 2014b). La Horda Dorada: Tensiones y Ambigüedades en Torno de Recursos y Repertorios Ligados al Hippismo. la Bohemia y los Movimientos Contraculturales de los 60' y los 70' en la Ciudad de Villa Gesell (Argentina). Trabajo presentado en el XI ${ }^{\circ}$ Congreso Argentino de Antropología Social. Rosario. 
Noel, G. \& de Abrantes, L. (2014). La Gran División. Crecimiento y Diferenciación Social en una Ciudad de la Costa Atlántica Bonaerense. Argumentos, 16, 141-166

Ortiz, C. (2010). Los Incautos. Historia de Villa Gesell y sus Alrededores. Buenos Aires: Alfonsina.

Oviedo, J. (2002). El Alma Perdida de Gesell. Ensayo sobre los Años Sesenta y Parte de los Setenta en la Villa. Villa Gesell: Edición de autor.

Oviedo, J. (2006). No Todo lo que Reluce es Oro (Primera Parte). Villa Gesell: Edición de autor.

Oviedo, J. (2007). No Todo lo que Reluce es Oro (Segunda Parte). Villa Gesell: Edición de autor.

Oviedo, J. (2009). Balneario Rico. Pueblo Pobre. Villa Gesell: Edición de autor.

Pastoriza, E. (2011). La Conquista de las Vacaciones. Breve Historia del Turismo en la Argentina. Buenos Aires: Edhasa.

Pastormerlo, S. (1996). Don Segundo Sombra. Un Campo sin Cangrejales. Orbis Tertius, I, 2-3.

Pereyra, S., Vommaro, G. \& Pérez, G. (2013). La Grieta. Política. Economía y Cultura después de 2001. Buenos Aires: Biblos.

Ratier, H. (1973). Villeros y Villas Miseria. Buenos Aires: Centro Editor de América Latina.

Regalsky, A. \& Da Orden, M. L. (2013). Banca y Finanzas Públicas. En J. M.
Palacio (Ed.), De la Federalización de Buenos Aires hasta el Advenimiento del Peronismo. Historia de la Provincia de Buenos Aires (pp. 251-283). Tomo 4. Buenos Aires: UNIPE-Edhasa.

Saccomanno, G. (1994). El Viejo Gesell. Buenos Aires: Alfonsina.

Sebreli, J. J. (1970). Mar del Plata. El Ocio Represivo. Buenos Aires: Tiempo Contemporáneo.

Sennett, R. (1982). La Autoridad. Madrid: Alianza Universidad.

Sierra, D. (1969). El Domador de Médanos. Buenos Aires: Ediciones Gesell.

Svampa, M. (Invierno 2004). Relaciones Peligrosas. Sobre clases medias, gobierno peronista y movimientos piqueteros. $E l$ Rodaballo, X: 15, 3-9.

Svampa, M. (2005). La Sociedad Excluyente. La Argentina bajo el Signo del Neoliberalismo. Buenos Aires: Taurus.

Tauber, F. (Comp.) (1998). Villa Gesell. Reflexiones y Datos para una Estrategia de Desarrollo. La Plata: Secretaría de Extensión de la UNLP.

Visacovsky, S. \& Garguin, E. (2009). Moralidades. Economías e Identidades de Clase Media. Estudios Históricos y Etnográficos. Buenos Aires: Antropofagia. Weber, M. (1993) [1905]. La Ética Protestante y el Espiritu del Capitalismo. Madrid: Península.

Wilkis, A. (2013). Las Sospechas del Dinero. Moral y Economía en la Vida Popular. Buenos Aires: Paidós. 
